\title{
Health numeracy and health literacy within the context of management of patients with human immunodeficiency virus
}

This article was published in the following Dove Press journal:

Nursing: Research and Reviews

2I February 2012

Number of times this article has been viewed

\author{
C Ann Gakumo' \\ David E Vance ${ }^{1,2}$ \\ Linda D Moneyham' \\ Joy P Deupree' \\ Carlos A Estrada 3,4 \\ 'School of Nursing, ${ }^{2}$ Center for \\ Nursing Research, ${ }^{3}$ Veterans Affairs \\ National Quality Scholars Program \\ at the Birmingham Veterans Affairs \\ Medical Center, ${ }^{4}$ School of Medicine, \\ University of Alabama at Birmingham, \\ Birmingham, AL, USA
}

\begin{abstract}
Health literacy, although an important topic in human immunodeficiency virus (HIV), often eclipses health numeracy, which may be equally important for those living with this disease. Health numeracy is the knowledge and application of numerical concepts in health decisions. In our synthesis of the literature, the emerging concept of health numeracy in relation to HIV disease management is reviewed within the context of health literacy. Specifically, we examine health literacy and numeracy by gender, race, education, and age group. From this synthesis, we identify practical implications of health numeracy related to HIV.

Keywords: health literacy, health numeracy, human immunodeficiency virus, acquired immune deficiency syndrome, medication adherence
\end{abstract}

\section{Introduction}

Patients with any recent diagnosis or chronic medical condition must process a great deal of new information. They need to learn about the origins of the disease, its cause, and the potential treatment options, if any. Also, patients need to understand how the disease affects them, requiring them to quickly learn new terms and concepts about normal human physiology as well as disease pathologies. In addition, patients must correctly interpret the health information provided. The responsibilities of navigating a complex health care system can be particularly difficult for low-literate individuals. Unfortunately, being diagnosed with any disease, particularly a disease that is stigmatizing or life-threatening, such as human immunodeficiency virus (HIV), can produce anxiety and depression. Such negative affect can interfere with learning and processing new information. ${ }^{1}$ The general consensus is that it is important for patients to possess and utilize medical information to make better informed treatment decisions, ${ }^{2}$ however, it is unclear whether patients actually process and apply this information in the way it is intended. For this reason, understanding health literacy and health numeracy is especially relevant for clinical populations.

Health literacy is the capacity of an individual to understand and utilize health information and services in making informed health decisions. ${ }^{3}$ In 2003 , nearly 80 million US adults (36\%) had limited health literacy. ${ }^{3}$ Health literacy includes an array of skills, including the ability to interpret documents accurately, read and write, and communicate effectively in order to function adequately in the health care system. ${ }^{4}$ Although much attention over the past decade has been paid to health literacy and its effect on health outcomes, there is a current trend of research focused on health numeracy as a separate construct rather than as a component of health literacy. ${ }^{5}$
Correspondence: C Ann Gakumo

School of Nursing, Room 548, 1720 2nd

Ave S., University of Alabama

at Birmingham, Birmingham,

AL 35294-1210, USA

Tel +l 2059965547

Fax +l 2059969165

Email cagakumo@uab.edu 
The concept of health numeracy has recently been addressed in the literature on HIV-related health outcomes, ${ }^{6,7}$ as well as other areas of health, such as anticoagulation control, ${ }^{8}$ diabetes, ${ }^{9}$ and self-management of asthma. ${ }^{10}$ However, it is important to distinguish between basic numeracy and health numeracy. Whereas numeracy is the understanding and use of numbers in daily life, ${ }^{11}$ health numeracy extends this concept to health-related phenomena. More specifically, it has been defined as "the degree to which individuals have the capacity to access, process, interpret, communicate, and act on numerical, quantitative, graphical, biostatistical, and probabilistic health information needed to make effective health decisions". 5

The purpose of this paper was to examine and synthesize the concept of health numeracy within the context of HIV disease management. In order to do so, we provide a brief review of health literacy as a backdrop to the emerging concept of health numeracy in HIV. Following this, we provide a specific focus on health numeracy in HIV, while examining specific clinical populations, including education level, gender, age, and race. As depicted in Figure 1, individuals with less education, older adults, males, and minorities have been associated with disparities in health literacy. We begin to tease apart similarities and differences in these groups within the literature on both health literacy and health numeracy. From this, we suggest implications for nursing practice and research.

\section{Health literacy versus health numeracy}

Health literacy and health numeracy are related concepts that are both important in making informed choices for healthy lifestyles, yet require a different set of skills. ${ }^{9}$ Based on the National Center for Education Statistics, a greater percentage of US adults have limited numeracy skills (22\%) when compared with other types of literacy skills (14\% limited in prose literacy and $12 \%$ limited in document literacy). ${ }^{12}$ Although some patients have adequate health literacy, a great majority are found to have inadequate health numeracy. ${ }^{11,13}$ In other words, although some individuals have a basic understanding of health information and services, many still lack numerical understanding at the level required for making health decisions. Thus, the importance of health numeracy in relation to health-related decisions and outcomes cannot be overstated.

The association between health literacy and health numeracy with regard to health services and outcomes has recently been reviewed by Berkman et al. ${ }^{4}$ Based on their review of the studies examining both health literacy and health numeracy $(n=4)$, health numeracy was more highly correlated than health literacy with patient outcomes. For example, one study ${ }^{14}$ examined health literacy, general numeracy, and diabetes-related health numeracy in a sample of adults with type 2 diabetes $(n=383)$. Their findings indicated that low levels of diabetes-related health numeracy, not health literacy, were associated with poor glycemic control. Health numeracy may reflect the actual application of health-related information because people may be able to use quantitative data more easily to achieve better health outcomes. These findings highlight the need for a stronger focus on the concept of health numeracy for HIV disease management and outcomes.

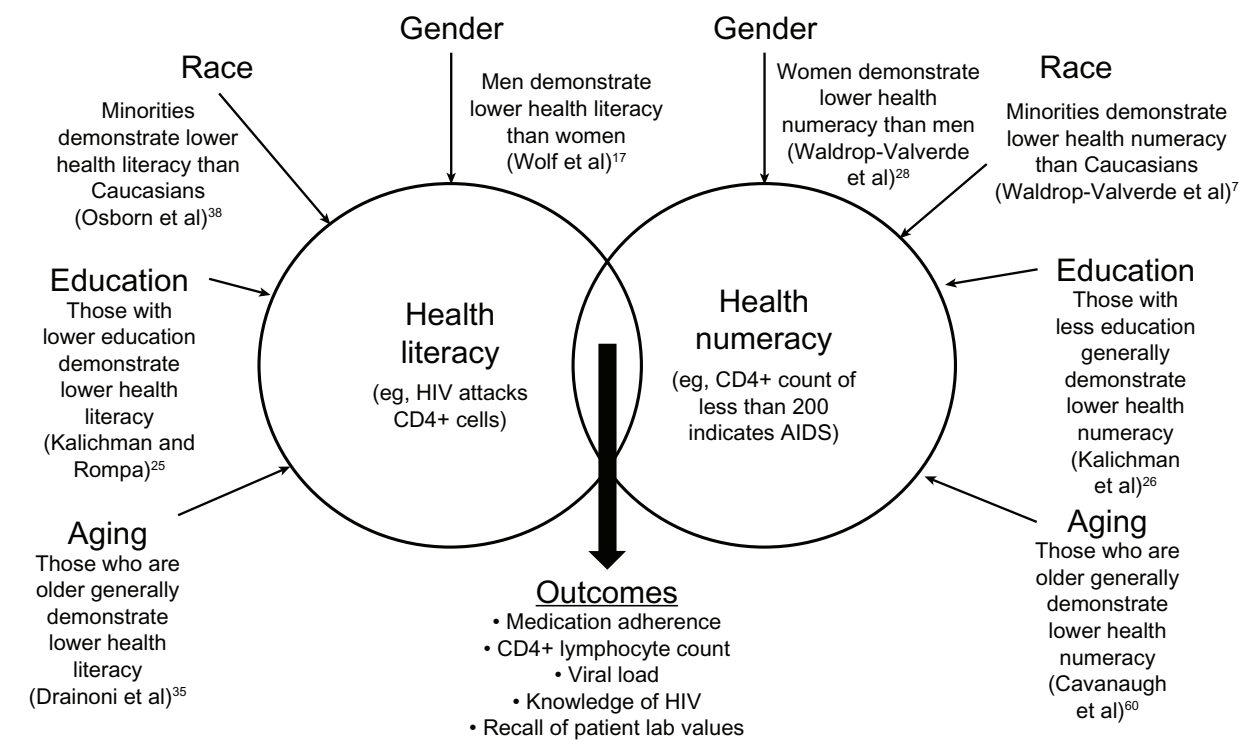

Figure I Overlap of health literacy and health numeracy that may relate to HIV. 


\section{Health literacy, health numeracy, and HIV}

Health literacy is especially important for individuals living with HIV because those with inadequate health literacy skills are less knowledgeable about their HIV disease and treatment and are also less likely to adhere to treatment. ${ }^{15-17}$ For example, in a study examining the relationship between health literacy and health-related knowledge of individuals with HIV ( $n=228)$, those with lower levels of health literacy were less likely to have undetectable viral loads and less likely to actually know their CD4+ lymphocyte counts and viral loads. ${ }^{15}$ Similarly, in another study of 204 individuals with $\mathrm{HIV},{ }^{18}$ patients with limited health literacy were less likely to report correctly their CD4+ lymphocyte counts and viral loads, and less likely to identify their antiretroviral medications correctly.

Health numeracy is relevant for individuals with HIV because much of their health information is quantitative. Successful management of HIV requires a great deal of quantitative information, such as counting pills and medication timing, as well as monitoring and interpreting one's CD4+ lymphocyte count and viral load, eg, a CD4+ lymphocyte count below 200 is indicative of acquired immune deficiency syndrome (AIDS). Furthermore, as individuals with HIV live longer, they are more likely to develop other chronic medical conditions such as hypertension, hyperlipidemia, and diabetes. ${ }^{19,20}$ These conditions also require proficiency in numeracy skills to promote healthy decision-making and wellness. For example, although it is important for patients to be literate about their lipid levels to decrease their risk of heart disease, eg, ("My LDL [low-density lipoprotein] is my bad cholesterol which can cause clogging in my arteries"), it is equally important to know what numerical values can decrease this risk (eg, "My goal for my next doctor's visit is to get my LDL below 100"). Tables 1 and 2 provide numeric information associated with HIV and related comorbidities.

The relationship between limited health literacy and increasingly disparate health outcomes is well noted in the literature among individuals with limited educational backgrounds, as well as among minority populations and older adults. ${ }^{21}$ However, health numeracy is not as prevalent in the scientific literature. In the following sections, health literacy and health numeracy by education level, gender, age group, and race are briefly examined within the context of HIV. It should be noted that although the literature in health numeracy is limited, the expected direction of relationships (eg, minorities demonstrate worse health numeracy than Caucasians) is similar to studies in health literacy.

\section{Educational differences}

Poor health literacy has been associated with lower education levels in numerous studies. ${ }^{22-24}$ Kalichman and Rompa ${ }^{25}$ examined health literacy in individuals with HIV and found that those with limited health literacy were more likely to have less years of formal education than those with higher health literacy $(n=338)$. On the other hand, a higher level of education may not necessarily translate into higher health literacy levels. In a study of individuals with HIV on antiretroviral therapy, ${ }^{18}(\mathrm{n}=204)$ more than $60 \%$ of the sample reported having some college education; however, $30 \%$ had less than a high school reading level (ie, health literacy level) when administered a health-related reading test. Interestingly, health literacy has been shown to be a stronger predictor of antiretroviral medication adherence than years of education. ${ }^{23}$

An early study ${ }^{26}$ found a significant positive correlation between health literacy and health numeracy in individuals with HIV ( $\mathrm{n}=184 ; 54 \%$ African-American). Health literacy was measured by a shortened version of the Test of Functional Health Literacy in Adults (TOFHLA). ${ }^{27}$ Health numeracy was measured by the numeracy scale of the TOFHLA. Although health literacy was examined in association with patients' adherence to combination antiretroviral therapies, health numeracy was only measured to validate the TOFHLA internally. Among the overall findings, the relationship between health literacy and medication adherence was not significant for participants with fewer than 12 years of education, but significant for participants with 12 or more years of education. Thus, within the more highly educated subsample, those with lower health literacy scores were less likely to be adherent to their medications when compared to those with higher health literacy scores.

\section{Gender differences}

The literature supports the existence of gender differences in both health literacy and health numeracy. For example, the National Center for Education Statistics found that although women had slightly higher scores than men in reading/ comprehension of health information, men had significantly higher scores than women in numeracy skills. ${ }^{12}$ A study of health literacy among 204 individuals with HIV $^{17}$ found that males were significantly more likely to have limited health literacy than females.

Waldrop-Valverde et a ${ }^{28}$ examined the relationship of health literacy, health numeracy, and HIV medication management by gender in a sample of patients recruited from 
Table I Numeric health information associated with human immunodeficiency virus

\begin{tabular}{|c|c|c|c|}
\hline $\begin{array}{l}\text { Quantitative } \\
\text { information }\end{array}$ & $\begin{array}{l}\text { Quantitative } \\
\text { values }\end{array}$ & Interpretation & Example \\
\hline ART regimen & $\begin{array}{l}\text { - Number of pills } \\
\text { - Dosage of pills } \\
\text { - Frequency of pills } \\
\text { - Time of day }\end{array}$ & $\begin{array}{l}95 \% \text { adherence rate is expected } \\
\text { for optimal viral suppression }{ }^{61}\end{array}$ & $\begin{array}{l}\text { Patient with I dose a day who } \\
\text { missed only } 3 \text { doses during the } \\
\text { past month may think they are } \\
\text { adherent, but are } 90 \% \text { adherent }\end{array}$ \\
\hline Clinic visits & $\begin{array}{l}\text { - Date of visit } \\
\text { - Time of visit } \\
\text { - Frequency of visits }\end{array}$ & $\begin{array}{l}\text { Missed clinic visits are associated } \\
\text { with virologic failure and disease } \\
\text { progression }^{66}\end{array}$ & $\begin{array}{l}\text { Patient nonadherent to clinic } \\
\text { visits or unable to access care } \\
\text { may miss laboratory tests or } \\
\text { instructions for medication } \\
\text { regimen }\end{array}$ \\
\hline CD4 & $\begin{array}{l}\text { - } 500-1500 \mathrm{~mm}^{3} \\
\text { - }<350 \mathrm{~mm}^{3} \\
\text { - }<200 \mathrm{~mm}^{3}\end{array}$ & $\begin{array}{l}\text { - } 500-1500 \mathrm{~mm}^{3} \text { (normal range) } \\
\text { - }<350 \mathrm{~mm}^{3} \text { (begin ART regimen) } \\
\text { - }<200 \mathrm{~mm}^{3} \text { progression to AIDS }{ }^{62}\end{array}$ & $\begin{array}{l}\text { Patient may misinterpret goal of } \\
\text { treatment (eg, "I take my meds } \\
\text { to make my CD4 go down") }\end{array}$ \\
\hline VL & $\begin{array}{l}\text { - }<50 \text { copies } / \mathrm{mL} \\
\text { - } \geq 50 \text { copies } / \mathrm{mL}\end{array}$ & $\begin{array}{l}-<50 \text { copies } / \mathrm{mL} \text { (HIV undetectable) } \\
-\geq 50 \text { copies/mL (HIV detectable) }\end{array}$ & $\begin{array}{l}\text { Patient may misinterpret goal of } \\
\text { treatment (eg, "I take my meds } \\
\text { to make my VL go up") }\end{array}$ \\
\hline
\end{tabular}

Abbreviations: ART, antiretroviral therapy; CD4, CD4+ lymphocyte count; VL, viral load.

affiliated HIV care clinics in the Southeast US ( $\mathrm{n}=155$; $87 \%$ African-American). Health literacy was measured by the reading comprehension subscale of the TOFHLA. Health numeracy was measured by the applied problems subscale of the Woodcock Johnson-III Tests of Achievement, ie, the mathematical problem is read aloud by the examiner and the participant decides the appropriate mathematical calculation..$^{29}$ Although no significant differences were noted between men and women in the health literacy measure, women scored significantly lower than men on the numeracy measure. Women also scored significantly lower in understanding HIV medication instructions, although this relation- ship was negated by numeracy. Thus, gender differences in numeracy have important implications for health disparities because men may be more likely to understand and adhere to quantitative medical information than women.

\section{Age differences}

Health literacy is poorer among older adults as compared with the general population. ${ }^{21,30}$ Regardless of educational background, more than two-thirds of US adults aged 60 years or older have low or marginal literacy skills. ${ }^{31}$ Using the Short Test of Functional Health Literacy in Adults, ${ }^{32}$ Gazmararian et $\mathrm{al}^{33}$ examined health literacy among Medicare enrollees

Table 2 Numeric health information associated with HIV-related comorbidities

\begin{tabular}{|c|c|c|c|}
\hline $\begin{array}{l}\text { Quantitative } \\
\text { information }\end{array}$ & $\begin{array}{l}\text { Quantitative } \\
\text { values }\end{array}$ & Interpretation & Example \\
\hline $\begin{array}{l}\text { BP } \\
\text { Comorbidity } \\
\text { Hypertension }\end{array}$ & $\begin{array}{l}\text { - }<120 / 80 \mathrm{mmHg} \\
\text { - } 120 / 80-139 / 89 \mathrm{mmHg} \\
\text { - } 140 / 90-159 / 99 \mathrm{mmHg} \\
\text { - } \geq 160 / 100 \mathrm{mmHg} \\
\text { - } \geq 180 / 110 \mathrm{mmHg}\end{array}$ & $\begin{array}{l}\text { - }<120 / 80 \mathrm{mmHg} \text { (normal) } \\
\text { - } 120 / 80-139 / 89 \mathrm{mmHg} \text { (prehypertension) } \\
\text { - } 140 / 90-159 / 99 \mathrm{mmHg} \text { (hypertension, stage I) } \\
\text { - } \geq 160 / 100 \mathrm{mmHg} \text { (hypertension - stage 2) } \\
\text { - } \geq 180 / 110 \mathrm{mmHg} \text { (hypertensive crisis) }\end{array}$ & $\begin{array}{l}\text { Patient may think } \\
\text { a systolic BP in the } \\
\text { I40s is normal }\end{array}$ \\
\hline $\begin{array}{l}\text { BG } \\
\text { Comorbidity } \\
\text { Diabetes }\end{array}$ & $\begin{array}{l}\text { - Fasting BG } \geq 126 \mathrm{mg} / \mathrm{dL} \\
\text { - 2-hr oral glucose tolerance } \\
\text { test } \geq 200 \mathrm{mg} / \mathrm{dL} \\
\text { - Random BG } \geq 200 \mathrm{mg} / \mathrm{dL} \\
\text { - Fasting BG } 100-125 \mathrm{mg} / \mathrm{dL}\end{array}$ & $\begin{array}{l}\text { - Diagnosis of diabetes: } \\
\text { - Fasting } B G \geq 126 \mathrm{mg} / \mathrm{dL} \\
\text { - } 2 \text {-hr oral glucose tolerance test } \geq 200 \mathrm{mg} / \mathrm{dL} \\
\text { - Random BG } \geq 200 \mathrm{mg} / \mathrm{dL} \\
\text { - Diagnosis of prediabetes: } \\
\text { - Fasting BG } 100-125 \mathrm{mg} / \mathrm{dL}^{64}\end{array}$ & $\begin{array}{l}\text { Patient may not } \\
\text { know normal blood } \\
\text { glucose values }\end{array}$ \\
\hline $\begin{array}{l}\text { LDL } \\
\text { HDL } \\
\text { Total cholesterol } \\
\text { Triglycerides } \\
\text { Comorbidity } \\
\text { Hyperlipidemia }\end{array}$ & $\begin{array}{l}\text { - } \mathrm{LDL} 70-130 \mathrm{mg} / \mathrm{dL} \\
\text { - } \mathrm{HDL}>40-60 \mathrm{mg} / \mathrm{dL} \\
\text { - Total cholesterol }<200 \mathrm{mg} / \mathrm{dL} \\
\text { - Triglycerides } 10-150 \mathrm{mg} / \mathrm{dL}\end{array}$ & $\begin{array}{l}\text { - } \mathrm{LDL},<100 \mathrm{mg} / \mathrm{dL} \text { is optimal } \\
\text { - } \mathrm{HDL}, \geq 60 \mathrm{mg} / \mathrm{dL} \text { is optimal } \\
\text { - Total cholesterol, }<200 \mathrm{mg} / \mathrm{dL} \text { is optimal } \\
\text { - Triglycerides, }<150 \mathrm{mg} / \mathrm{dL} \text { is optimal }{ }^{65}\end{array}$ & $\begin{array}{l}\text { Patients may } \\
\text { confuse HDL with } \\
\text { LDL (eg, "I want to } \\
\text { keep my LDL high } \\
\text { and my HDL low.") }\end{array}$ \\
\hline
\end{tabular}

Abbreviations: BP, blood pressure; BG, blood glucose; LDL, low-density lipoprotein; HDL, high-density lipoprotein. 
across the US $(n=3260)$. These researchers found that $33.9 \%$ of English-speaking and 53.9\% of Spanish-speaking adults aged 65 years or older had inadequate or marginal health literacy. Level of education and cognitive impairment were also associated with lower health literacy. Even after controlling for these two factors, health literacy declined significantly with age. ${ }^{33}$ Unfortunately, health numeracy was not measured, but given what is known about the close relationship between health literacy and health numeracy, older adults in general may also possess poorer health numeracy skills which could impact their health outcomes. Murphy et a ${ }^{34}$ conducted one of the first studies on health literacy in adolescents with HIV, and found no relationship between health literacy and antiretroviral adherence in this population $(\mathrm{n}=186$; mean age 20.5 years). In adults with HIV, Drainoni et a ${ }^{35}$ reported a relationship between older age and poorer health literacy while other studies ${ }^{17,23,25}$ found no association.

In developed countries where patients have access to antiretroviral medication, nearly half of those with HIV will be 50 years and older by $2015 .{ }^{36}$ Little is known about health literacy and health numeracy in this burgeoning clinical population. Given that comorbidities increase with advanced age in adults with $\mathrm{HIV},{ }^{20}$ older patients will be juggling a great deal of medical information to help inform health care decision-making (see Table 2). Juggling such information may be particularly difficult for many older adults with HIV who are vulnerable to neurological insults resulting in poor memory and trouble with reasoning and planning. ${ }^{37}$ Thus, more information is needed on how health literacy and health numeracy, along with cognitive problems, will impact health outcomes in this growing population.

\section{Racial differences}

Osborn et $\mathrm{al}^{38}$ examined the mediating effect of health literacy on the relationship between race and HIV medication adherence. Health literacy was measured by the Rapid Estimate of Adult Literacy in Medicine. ${ }^{39}$ The task involves asking the participant to read aloud a list of medical words (eg, "pill", "prescription", "medication") and scoring for correct pronunciation. In their sample ( $n=204 ; 45 \%$ African-American), they found that African-American patients were significantly more likely to be nonadherent with their HIV medications than their Caucasian counterparts. However, when health literacy was included in the model, the effect of race was not significant. ${ }^{38}$

Building on the previous study, Waldrop-Valverde et $\mathrm{al}^{7}$ examined numeracy as a potential mediator between race and medication management among patients recruited from an infectious disease clinic and an AIDS drug assistance program ( $n=207 ; 84 \%$ African-American). Health literacy was measured by the reading comprehension subscale of the TOFHLA and numeracy was measured by the Applied Problems subscale of the Woodcock Johnson-III. ${ }^{29}$ Using a simulated medication regimen approach in which participants were questioned about a series of mock HIV medication instruction labels, African-Americans were less likely than non-AfricanAmericans to follow medication instructions correctly. Interestingly, although no differences in health literacy scores were noted between races, African-Americans scored significantly lower in numeracy scores than their non-African American counterparts. Moreover, the relationship between race and HIV medication management was negated by numeracy. ${ }^{\text {? }}$ Thus, health numeracy skills may be an important predictor in explaining racial disparities that exist for African-Americans in HIV medication adherence and management.

Although the majority of HIV studies that examine racial disparities in health literacy and health numeracy focus on African-Americans, recent studies address disparities in the Latino population. In their study of a high-risk sample of individuals with HIV $(\mathrm{n}=231)$, Drainoni et $\mathrm{al}^{35}$ found that Latinos were four times as likely to have limited health literacy as Caucasians, and those whose native language was Spanish were twice as likely as native-English speakers to have lower health literacy. Health literacy interventions targeting this specific population have also been noted in the literature. ${ }^{40}$

\section{Implications for nursing practice}

Nurses are on the forefront in efforts to address both health literacy and health numeracy concerns and patient outcomes in health care. What may seem simple and straightforward among health care professionals may be difficult for patients to understand, regardless of their level of education. With the concept of health numeracy emerging from the health literacy movement, there are numerous opportunities for nurse leaders to provide the infrastructure for improved patient understanding within the context of HIV disease management.

\section{Nursing curricula and continuing education}

Whether dealing with a new disease process, discharge teaching, or managing a chronic condition, nurses often provide one-on-one health education to patients..$^{41}$ To prepare those diagnosed with HIV for self-management of a complex medication regime properly, nurses must be educated to: conduct a patient risk assessment for low health literacy 
and health numeracy; identify the knowledge level of each patient; and prepare patient education materials at the appropriate reading and numeracy levels. ${ }^{42}$

In response to health literacy reports by the Joint Commission $^{43}$ and Healthy People $2020^{2,44}$ nursing schools have begun to explore curricula revision to include a health literacy component. Nielsen-Bohlman et $\mathrm{al}^{3}$ noted the necessity of revising nursing education curricula to include content preparing health care professionals to identify patients with low health literacy skills (numeracy and reading comprehension). To prepare patients effectively for a complex self-management care plan involving functional numeracy skills, nurses must be prepared by undergraduate and graduate level curricula to communicate effectively with patients. ${ }^{42}$

Experienced nurses may also need continuing education to understand fully and recognize the risks associated with limited health literacy and health numeracy. In a study of an academic health center, Jukkala et $\mathrm{al}^{45}$ examined health care providers' and college students' knowledge of the impact of health literacy on patients and the health care system $(n=230)$. Participants in the study included nursing, dentistry, and medical professionals, as well as college students. Among health care professionals, nurses had the highest percentage of knowledge deficits in health literacy (17.1\%). Furthermore, only $8.5 \%$ of nurses in the sample $(n=7)$ had knowledge of the growing percentage of adults with difficulty understanding health care information and instructions.

\section{Patient communication and participatory decision-making}

In general, patients want to know more about their disease, ${ }^{46}$ but those with limited health literacy and numeracy may be unlikely to ask questions about things they do not understand. Furthermore, health care providers in the HIV care setting may not easily perceive that their patients face health literacy and numeracy barriers to care. ${ }^{47}$ For this reason, it is ethically imperative that verbal and written health communication to all patients be relayed in a way that is clear and easy to understand. Recently, national efforts have been made to provide nurses and other health care professionals with the tools they need to address issues of limited health literacy and numeracy in their patient populations. ${ }^{48,49}$ Although further testing is needed to determine the effectiveness of these programs, this is an important step in engaging the patient as an active participant in the plan of care. Participatory decisionmaking involves a collaborative relationship between the patient and the nurse, characterized by actively communicating to improve the patient's understanding and involvement in decision-making for better health outcomes. ${ }^{50}$ For individuals with HIV, such a relationship is invaluable to understanding laboratory values and a complex treatment plan.

\section{Implications for nursing research}

The complex concept of health numeracy has important implications for nursing research. Although recent strides have been made in examining the relationship between health numeracy and health outcomes, much work is needed to advance the field in HIV. In particular, instrument development and interventional studies are needed.

General numeracy instruments lack any real concrete example within a context of health and medicine. ${ }^{51-53}$ Health numeracy instruments that are HIV disease-specific would resonate with patients and be more applicable to health outcomes than general numeracy instruments. Unfortunately, there are no instruments that specifically focus on health numeracy related to HIV; however, there are two health literacy instruments that come close.

Osborn et $\mathrm{al}^{54}$ developed a health literacy instrument within the context of HIV disease treatment, ie, the Brief Estimate of Health Knowledge and Action - HIV Version (BEHKA-HIV). This eight-item instrument was designed to assess knowledge of CD4 lymphocyte count, viral load, and current HIV medications, as well as medication adherence. Its subscales have reported reliability coefficients of 0.73 and 0.79. ${ }^{54}$ What is interesting about the BEHKA-HIV is that there are two items that are somewhat related to HIV health numeracy (ie, "Is the goal of treatment to make the CD4 count go up or down?" and "Is the goal of treatment to make the viral load go up or down?"). Although no real numbers or ranges of optimal or suboptimal values are asked, these two items reflect a cursory understanding of the importance of health numeracy related to HIV. Obviously, it would be helpful to know if a CD4 count of 199 is good or bad or whether a viral load that increases to one million is harmful. Future development of instruments should take such items into account, as well as other numeracy items related to medication schedules, and clinic appointments (see Table 1).

More recently, Ownby et al ${ }^{55}$ developed the HIV-Related Health Literacy (HIV-HL) scale. This computer-administered, 20 -item instrument assesses skills in taking medications properly and has several items related to HIV infection and treatment. Although the instrument has a stronger focus on health literacy, there are numeracy-type items included. For example, participants must understand basic numerical items ("Take two pills two times a day") as well as more 
complex numerical items ("If you take two pills two times a day, how long will this prescription last?"). The reported reliability coefficient of the revised 19-item HIV-HL was $0.69 .^{55}$ Although the development of this instrument advances the field primarily through evaluating listening comprehension, it requires further testing in a clinical setting.

There have been numerous intervention studies focused on improving health literacy to promote health outcomes among those living with HIV. ${ }^{35,40,56}$ The majority of studies on health numeracy have so far been descriptive. HIV studies in particular have thus far primarily examined relationships between health numeracy and medication adherence. ${ }^{7,28,57}$ Future intervention studies in HIV should incorporate graphics and visual displays of the numerical values being presented to facilitate comprehension in patients with HIV. ${ }^{55,58}$

Health numeracy research should focus on developing interventions that improve understanding of quantitative health information to improve health outcomes not only in medication adherence, but also in understanding laboratory values. A participatory design method with low healthnumerate individuals can be used to determine how patients understand numerical information as well as patient preferences on how they like to receive this information. An intervention can then be developed based on these preferences and tested for feasibility and effectiveness on health outcomes. Such health numeracy interventions should also be tailored to specific clinical populations and socially disadvantaged groups most affected, such as African-Americans and/or older adults with HIV, especially those with cognitive deficits.

\section{Limitations}

Our synthesis of the literature has its limitations. Although we discuss a brief review of the literature on health literacy, the main purpose of our manuscript is to discuss the emerging concept of health numeracy. Thus, our synthesis is not a complete review of the research in health literacy. Furthermore, Figure 1, which depicts an overview of demographic considerations in health literacy and numeracy, reflects a limited number of studies and should be viewed as a starting point for future research. For example, there is a dearth of health numeracy research in the aging population, because the majority of HIV studies do not include a significant number of individuals over the age of 50 years from which to draw age group comparisons. This is an important gap to address, as the population aging with HIV continues to grow. ${ }^{36}$

\section{Conclusion}

As part of President Obama's National HIV/AIDS Strategy, ${ }^{59}$ which focuses in large part on reducing HIVrelated health disparities and inequities and increasing access to care, health literacy and health numeracy are clearly important topics. There has been a recent trend towards health numeracy studies that focus on chronic diseases such as diabetes. ${ }^{14,60}$ However, more research is needed to disentangle the separate effects of health literacy and health numeracy in HIV (Figure 1). The focus on health numeracy and its effects on HIV disease progression are important not only for patients with HIV but also for caregivers, educators, clinicians, and researchers within this growing field.

\section{Disclosure}

The authors report no real or perceived vested interests that relate to this article (including relationships with pharmaceutical companies, biomedical device manufacturers, grantors, or other entities whose products or services are related to topics covered in this manuscript) that could be construed as a conflict of interest.

\section{References}

1. Chance P. Learn and Behavior, 2nd ed. Belmont, CA: Wadsworth; 1988.

2. Healthy People 2020. Healthy People 2020 Summary of Objectives. Available from: http://healthypeople.gov/2020/topicsobjectives2020/ pdfs/HP2020objectives.pdf. Accessed November 13, 2012.

3. Nielsen-Bohlman L, Panzer AM, Kindig DA. Health Literacy: A Prescription to End Confusion. Washington, DC: The National Academies Press; 2004.

4. Berkman ND, Sheridan SL, Donahue KE, et al. Health literacy interventions and outcomes: an updated systematic review. Evidence report/technology assessment No 199. (Prepared by RTI International-University of North Carolina Evidence-based Practice Center under contract No 290-2007-10056-I). AHRQ Publication Number 11-E006. Rockville, MD: Agency for Healthcare Research and Quality; 2011. Available from: http://www.ahrq.gov/downloads/pub/evidence/pdf/literacy/literacyup. pdf. Accessed November 13, 2012.

5. Golbeck AL, Ahlers-Schmidt CR, Paschal AM, Dismuke SE. A definition and operational framework for health numeracy. Am J Prev Med. 2005;29:375-376.

6. Lu M, Safren SA, Skolnik PR. Optimal recall period and response task for self-reported HIV medication adherence. AIDS Behav. 2008; 12:86-94.

7. Waldrop-Valverde D, Osborn CY, Rodriguez A, Rothman RL, Kumar M, Jones DL. Numeracy skills explain racial differences in HIV medication management. AIDS Behavior. 2010;14:799-806.

8. Estrada CA, Martin-Hryniewicz M, Peek B, Collins C, Byrd J. Literacy and numeracy skills and anticoagulation control. Am J Med Sci. 2004;328:88-93.

9. Montori VM, Leung TW, Thompson CA, Chung JA, Capes SE, Smith SA. Choice of risk representation to enable diabetes decision-making. Diabetes. 2004;53 Supp1 2:A225.

10. Apter AJ, Cheng J, Small D, et al. Asthma numeracy skill and health literacy. J Asthma. 2006;4:705-710. 
11. Rothman RL, Housam R, Weiss H, et al. Patient understanding of food labels: the role of literacy and numeracy. Am J Prev Med. 2006;31: 391-398.

12. US Department of Education, National Center for Education Statistics, 2007. The Condition of Education 2007. Available from: http://nces. ed.gov/fastfacts/display.asp?id=69. Accessed November 12, 2012.

13. Golbeck A, Paschal A, Jones A, Hsiao T. Correlating reading comprehension and health numeracy among adults with low literacy. Patient Educ Couns. 2011;84:132-134.

14. Osborn CY, Cavanaugh K, Wallston KA, White RO, Rothman RL. Diabetes numeracy: an overlooked factor in understanding racial disparities in glycemic control. Diabetes Care. 2009;32:1614-1619.

15. Kalichman SC, Benotsch E, Suarez T, Catz S, Miller J, Rompa D. Health literacy and health-related knowledge among persons living with HIV/ AIDS. Am J Prev Med. 2000;18:325-331.

16. Miller LG, Liu H, Hays RD, et al. Knowledge of antiretroviral regimen dosing and adherence: a longitudinal study. Clin Infect Dis. 2003;36: 514-518.

17. Wolf MS, Davis TC, Osborn CY, Skripkauskas S, Bennett CL, Makoul G. Literacy, self-efficacy, and HIV medication adherence. Patient Educ Couns. 2007;65:253-260.

18. Wolf MS, Davis TC, Arozullah A. Relation between literacy and HIV treatment knowledge among patients on HAART regimens. AIDS Care. 2005; 17:863-873.

19. Rawlings MK, Masters HL. Comorbidities and challenges affecting African Americans with HIV infection. J Natl Med Assoc. 2008;100: 1477-1481

20. Vance DE, Mugavero M, Willig J, Raper JL, Saag MS. Aging with HIV: a cross-sectional study of co-morbidity prevalence and clinical characteristics across decades of life. JAssoc Nurses AIDS Care. 2011; 22:17-25.

21. Institute of Medicine. Health Literacy: A Prescription to End Confusion. Washington, DC: National Academies Press; 2004.

22. Beers BB, McDonald VJ, Quistberg DA, Ravenell KL, Asch D, Shea JA. Disparities in health literacy between African American and non-African American primary care patients. J Gen Intern Med. 2003;18 Suppl 1:169.

23. Kalichman SC, Pope H, White D, et al. The association between health literacy and HIV treatment adherence: further evidence from objectively measured medication adherence. J Int Assoc Physicians AIDS Care. 2008;7:317-323.

24. Nokes KM, Coleman CL, Cashen M, et al. Health literacy and health outcomes in HIV seropositive persons. Res Nurs Health. 2007;30: 620-627.

25. Kalichman SC, Rompa D. Functional health literacy is associated with health status and health-related knowledge in people living with HIV-AIDS. J Acquir Immune Defic Syndr. 2000;25:337-344.

26. Kalichman SC, Ramachandran B, Catz S. Adherence to combination antiretroviral therapies in HIV patients of low health literacy. J Gen Intern Med. 1999;14:267-273.

27. Parker RM, Baker DW, Williams MV, Nurss JR. The test of functional health literacy in adults: a new instrument for measuring patients' literacy skills. J Gen Intern Med. 1995;10:537-541.

28. Waldrop-Valverde D, Jones DL, Jayaweera D, et al. Gender differences in medication management capacity in HIV infection: the role of health literacy and numeracy. AIDS Behav. 2009;13:46-52.

29. Woodcock RW, McGrew KS, Mather N. Woodcock Johnson III Tests of Achievement. Itasca, IL: Riverside Publishing; 2001.

30. National Center for Education Statistics. National Assessment of Adult Literacy: A Nationally Representative and Continuing Assessment of English Language Literary Skills of American Adults. Washington, DC: National Center for Education Statistics; 2003.

31. Kirsch IS, Jungeblut A, Jenkins L (2002). Adult literacy in America: A first look at the findings of the National Adult Literacy Survey, $3^{\text {rd }}$ Edition. U.S. Department of Education: National Center for Education Statistics. Available from: http://nces.ed.gov/pubs93/93275.pdf. Accessed October 24, 2012.
32. Baker DW, Williams MV, Parker RM, Gazmararian JA, Nurss J. Development of a brief test to measure functional health literacy. Patient Educ Couns. 1999;38:33-42.

33. Gazmararian JA, Baker DW, Williams MV, et al. Health literacy among Medicare enrollees in a managed care organization. JAMA. 1999;281: 545-551.

34. Murphy DA, Lam P, Naar-King S, Harris DR, Parsons JT, Muenz LR. Health literacy and antiretroviral adherence among HIV-infected adolescents. Patient Educ Couns. 2010;79:25-29.

35. Drainoni ML, Rajabium S, Rumptz M, et al. Health literacy of HIV-positive individuals enrolled in an outreach intervention: results of a cross-site analysis. J Health Commun. 2008;13:287-302.

36. Kirk JB, Goetz MB. Human immunodeficiency virus in an aging population, a complication of success. J Am Geriatr Soc. 2009;57: 2129-2138

37. Vance DE. Aging with HIV: bringing the latest research to bear in providing care. Am J Nurs. 2010;110:2-7.

38. Osborn CY, Paasche-Orlow MK, Davis TC, Wolf MS. Health literacy: an overlooked factor in understanding HIV health disparities. Am J Prev Med. 2007;33:374-378.

39. Davis TC, Long SW, Jackson RH, et al. Rapid estimate of adult literacy in medicine: a shortened screening instrument. Fam Med. 1993;25: 391-395.

40. Servellen GV, Brown JS, Lombardi E, Herrera G. Health literacy in low-income Latino men and women receiving antiretroviral therapy in community-based treatment centers. AIDS Patient Care STDs. 2003;17: 283-298.

41. Wingard R. Patient education and the nursing process: meeting the patient's needs. Nephrol Nurs J. 2005;32:211-214.

42. Sand-Jecklin K, Murray B, Summers B, Watson J. Educating nursing students about health literacy: From the classroom to the patient bedside. The Online Journal of Issues in Nursing. 2010;15(3).

43. Joint Commission 2007. "What Did the Doctor Say?": Improving Health Literacy to Protect Patient Safety. Available from: http://www.jointcommission.org/assets/1/18/improving_health_literacy.pdf. Accessed November 13, 2012.

44. HealthyPeople.gov. Tools for Public Health Professionals, 2011. Available from: http:/healthypeople.gov/2020/connect/tools.aspx. Accessed November 13, 2012.

45. Jukkala A, Deupree JP, Graham S. Knowledge of limited health literacy at an academic center. J Contin Educ Nurs. 2009;40:298-302.

46. Whitney SN. A new model of medical decisions: exploring the limits of shared decision making. Med Decis Making. 2003;23:275-280.

47. Ohl M, Harris A, Nurudtinova D, Cai X, Drohobyczer D, Overton ET. Do brief screening questions or provider perception accurately identify persons with low health literacy in the HIV primary care setting? AIDS Patient Care STDs. 2010;24:623-629.

48. Baur $\mathrm{C}$, Brooks $\mathrm{C}$, editors. National action plan to improve health literacy. US Department of Health and Human Services. Available from: http://www.dhh.state.la.us/assets/docs/GovCouncil/MinHealth/ Health_Literacy_Action_Plan.pdf. Accessed November 13, 2012.

49. DeWalt DA, Callahan LF, Hawk VH, et al. Health literacy universal precautions toolkit. (Prepared by North Carolina Network Consortium, The Cecil G Sheps Center for Health Services Research, The University of North Carolina at Chapel Hill, under Contract HHSA290200710014.) AHRQ Publication 10-0046-EF. Rockville, MD: Agency for Healthcare Research and Quality; 2010. Available from: http://www.nchealthliteracy.org/toolkit/toolkit_w_appendix.pdf. Accessed November 13, 2012.

50. Epstein RM, Alper BS, Quill TE. Communicating evidence for participatory decision making. JAMA. 2004;291:2359-2366.

51. Fagerlin A, Zikmund-Fisher BJ, Ubel PA, Jankovic A, Derry HA, Smith DM. Measuring numeracy without a math test: development of the subjective numeracy scale. Med Decis Making. 2007;27:672-680.

52. Lipkus IM, Samsa G, Rimer BK. General performance on a numeracy scale among highly educated samples. Med Decis Making. 2001;21: $37-44$. 
53. Schwartz LM, Woloshin S, Black WC, Welch HG. The role of numeracy in understanding the benefit of screening mammography. Ann Intern Med. 1997;127:966-972.

54. Osborn CY, Davis TC, Bailey SC, Wolf MS. Health literacy in the context of HIV treatment: Introducing the brief estimate of health knowledge and action (BEHKA)-HIV version. AIDS Behav. 2010;14: $181-188$

55. Ownby RL, Waldrop-Valverde D, Hardigan P, Caballero J, Jacobs R, Acevedo A. Development and validation of a brief computeradministered HIV-related health literacy scale (HIV-HL). AIDS Behav. September 8, 2012. [Epub ahead of print.]

56. Kalichman SC, Cherry J, Cain D. Nurse-delivered antiretroviral treatment adherence intervention for people with low literacy skills and living with HIV/AIDS. J Assoc Nurs AIDS Care. 2005;16:3-15.

57. Waldrop-Valverde D, Jones DL, Gould F, Kumar M, Ownby RL. Neurocognition, health-related reading literacy, and numeracy in medication management for HIV infection. AIDS Patient Care STDs. 2010;24:477-484.

58. Moore JO, Boyer EW, Safren S, et al. Designing interventions to overcome poor numeracy and improve medication adherence in chronic illness, including HIV/AIDS. J Med Toxicol. 2011;7:133-138.

59. White House Office of National AIDS Policy. 2010. National HIV/AIDS Strategy for the United States. Available from: http://www.whitehouse. gov/sites/default/files/uploads/NHAS.pdf. Accessed November 13, 2012.
60. Cavanaugh K, Huizinga MM, Wallston KA, et al. Association of numeracy and diabetes control. Ann Intern Med. 2008;148:737-746.

61. Lima VD, Geller J, Bangsberg, et al. The effect of adherence on the association between depressive symptoms and mortality among HIV-infected individuals first initiating HAART. AIDS. 2007;21:1175-1183.

62. Kirton CA. Promoting healthy behaviors in HIV primary care. Nurse Pract Forum. 2001;12:223-232.

63. American Heart Association, 2011. Understanding blood pressure readings. Available from: http://www.heart.org/HEARTORG/ Conditions/HighBloodPressure/AboutHighBloodPressure/ Understanding-Blood-Pressure-Readings_UCM_301764_Article.jsp. Accessed November 13, 2012.

64. American Diabetes Association, 2010. Diagnosis and classification of diabetes mellitus. Available from: http://care.diabetesjournals.org/ content/31/Supplement_1/S55.full. Accessed November 13, 2012.

65. American Heart Association, 2011. What your cholesterol levels mean. Available from: http://www.heart.org/HEARTORG/Conditions/ Cholesterol/AboutCholesterol/What-Your-Cholesterol-Levels-Mean UCM_305562_Article.jsp. Accessed November 13, 2012.

66. Van Servellen GV, Carpio F, Lopez M, et al. Program to enhance health literacy and treatment adherence in low-income HIV-infected Latino men and women. AIDS Patient Care STDs. 2003;17:581-594.
Nursing: Research and Reviews

\section{Publish your work in this journal}

Nursing: Research and Reviews is an international, peer-reviewed, open access journal publishing original research, reports, reviews and commentaries on all aspects of nursing and patient care. These include patient education and counselling, ethics, management and organizational issues, diagnostics and prescribing, economics and

\section{Dovepress}

resource management, health outcomes, and improving patient safety in all settings. The manuscript management system is completely online and includes a very quick and fair peer-review system. Visit http://www.dovepress.com/testimonials.php to read real quotes from published authors. 